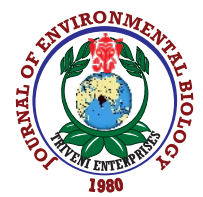

\title{
Influence of abiotic factors on stem borer incidence and species distribution in rice (Oryza sativa L.)
}

\author{
T. Sharmitha ${ }^{1}$, C.G.L.Justin ${ }^{2 *}$ and S.S.J. Roseleen ${ }^{2}$ \\ ${ }^{1}$ Department of Agricultural Entomology, Agricultural College and Research Institute, TNAU, Coimbatore- 641003 , India \\ ${ }^{2}$ Department of Plant Protection, Anbil Dharmalingam Agricultural College and Research Institute, TNAU, Tiruchirappalli-620 027, India
}

*Corresponding Author Email : tnaugailce@yahoo.com

\begin{abstract}
Aim: To evaluate the effect of abiotic factors such as temperature, relative humidity, wind velocity, sunshine hours and rainfall on the distribution and relative abundance of stem borer species in rice ecosystem.

Methodology: Seasonal incidence of stem borer species was monitored using light trap catches and were correlated with the weather parameters. The relative abundance of stem borer species during Kharifand Rabi was estimated based on light trap catches and larval incidence.

Results: Seasonal incidence revealed the occurrence of three stem borer species (yellow stem borer, pink stem borer and dark headed borer) populations in rice ecosystem. Yellow stem borer was found to dominate in rice ecosystem during Kharif, (80.61\%) whereas during Rabi, pinkstem borer was found to be dominant $(72.60 \%)$ than yellow stem borer $(21.92 \%)$ and dark headed borer $(5.48 \%)$. Weather parameters such as temperature, rainfall and wind velocity negatively influenced the occurrence of stem borer species in rice, whereas relative humidity and sunshine hours had positive effect. Regression analysis revealed the increased effect of abiotic factors such as temperature, relative humidity and wind velocityon the population of pink stem borer against yellow stem borer and dark headed borer.

Interpretation: The present study reveals that, the change in weather parameter during seasons, such as temperature $\left(25-27^{\circ} \mathrm{C}\right)$, relative humidity $(69$ $-80 \%$ ) and wind velocity ( $\left.3-4 \mathrm{~km} \mathrm{hr}^{-1}\right)$ increased the fitness of pink stem borer species population than yellow stem borer and dark headed borer species in rice ecosystem, which was evidenced by the occurrence and relative abundance of pink stem borer population during Kharif 2018 and Rabi 2019 respectively.
\end{abstract}

Key words: Abiotic factors, Light trap catches, Rice, Stem borer

\section{Light trap catches, Larval incidence}

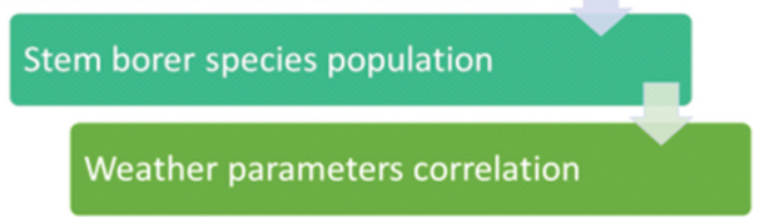

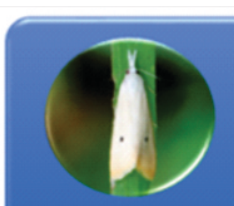

Yellow stem borer

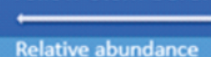

in Kharif
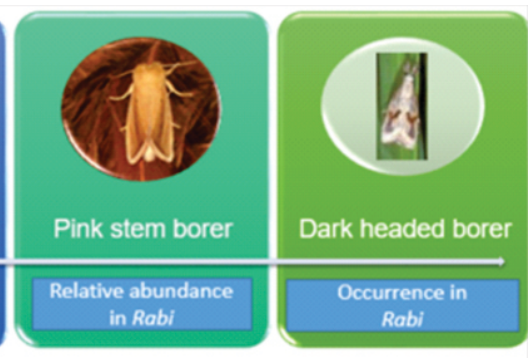

How to cite : Sharmitha T., C.G.L.Justinand S.S.J. Roseleen, Influence of abiotic factors on stem borer incidence and species distribution in rice (Oryza sativa L.) J. Environ. Biol., 42, 1126-1133 (2021). 


\section{Introduction}

Rice (Oryza sativa L.) belonging to family Poaceae is an important grain crop in the world feeding more than $50 \%$ of the human population (Fukagawa and Ziska, 2019). Globally, it is the second most cultivated cereal crop next to wheat. India ranks first in area (43.79 million ha) and second in rice production (109.70 MT) (Anon., 2018). Tamil Nadu is one among the major rice producing states in India. The productivity of rice crop is influenced by several biotic and abiotic factors. The rice crop is subjected to considerable damage by nearly 300 species of insect pests, among them 23 species are serious pests of rice (Pasalu et al., 2006). Yield loss due to insect pests of rice have been estimated to be $25 \%$ (Dhaliwal et al., 2010). About 40\% damage is caused by stem borer alone (Kumar et al., 2019). The young larva of stem borer primarily enters into the leaf sheath and feeds for two to three days, after which the larva enters the basal part usually 5 to $10 \mathrm{~cm}$ above water level and feeds inside the stem causing dying of central shoot known as dead heart at vegetative stage and white ear head is formed by boring at the peduncle node during heading stage (Gupta et al., 2006). The yellow stem borer, Scirpophaga incertulas (Walker), the pink stem borer, Sesamia inferens (Walker) and dark headed borer Chilo polychrysus (Meyrick) are poplyphagous pests of the Gramineae. Various abiotic factors influence the occurrence and population dynamics of paddy stem borers (Gagan et al., 2009). The changing climatic scenario with modern cultivation practices in rice crop has made pink stem borer to achieve key pest status in many rice growing regions of India, that causes dead heart, white ear and results in yield reduction (Sampath et al., 2014). In view of the above, the present study was conducted to examine the influence of abiotic factors on the occurrence and relative dominance of stem borer species in rice ecosystem at Tiruchirappalli, Tamil Nadu.

\section{Materials and Methods}

Rice crop (cv. TRY 3) was grown at the experimental farm of Anbil Dharmalingam Agricultural College and Research Institute, Tiruchirappalli District, Tamil Nadu, India, to monitor the seasonal incidence of rice stem borer species during Kharif, 2018 and Rabi,2019. Standard agronomic practices recommended by Tamil Nadu Agricultural University were adopted, except for plant protection measures and the rice crop was maintained during the entire period of study. A light trap unit made of galvanised iron sheet with a trapping device and collecting chamber was installed in the bund, at the centre of experimental area and operated from 7.00 p.m. to 11.00 p.m. with mercury vapour lamp of $160 \mathrm{~W}$ as the light source. The collecting jar with insecticide was changed every day and insects collected were counted each day and the species were assessed and sexed based on morphological characters (Hattori, 1971; Khan et al., 1991; Sharma et al., 2017) to arrive at weekly mean population.

The tillers expressing dead heart and white ear were cut opened at weekly intervals, during Kharif, 2018 and Rabi, 2019. The larvae collected were sorted out according to the morphological characters (Bhatt et al., 2018) and occurrence of stem borer species was assessed.

The relative abundance of the stem borer species based on light trap catches and larval incidence during Kharif and Rabi was assessed by the following formula:

Relative abundance $(\%)=($ Total no. of individuals of each species/Total no. of individuals of all species) X100

Data on weather parameters such as maximum temperature $\left({ }^{\circ} \mathrm{C}\right)$, minimum temperature $\left({ }^{\circ} \mathrm{C}\right)$, relative humidity $(\%)$, wind velocity $(\mathrm{km} / \mathrm{hr})$, sunshine hours $(\mathrm{hr})$ and rainfall $(\mathrm{mm})$ were obtained from the Agro-meteorological Station at Anbil Dharmalingam Agricultural College and Research Institute, Tiruchirappalli. The weather parameters were correlated with the weekly light trap catches and their effect on stem borer species occurrence and distribution in the paddy ecosystem was estimated by correlation and regression analysis.

\section{Results and Discussion}

Based on light trap catches, adult populations of three stem borer species, such as Yellow stem borer (YSB), Pink stem borer and Dark headed borer (DHB) have been observed to occur in the rice ecosystem at Agricultural College and Research Institute, Tiruchirappalli. It is in accordance with the previous report of occurrence of Yellow stem borer, Pink stem borer and Dark headed borer stem borer species in major rice growing areas of Tamil Nadu (Ragini et al.2000).Periodical observations on the stem borer species moth population revealed the incidence of Yellow stem borer in the second week of August, $32^{\text {nd }}$ Standard Meteorological Week (SMW), Pink stem borer in the second week of September ( $38^{\text {th }}$ SMW)and Dark headed borer in the third week of November ( $47^{\text {th }}$ SMW) and also revealed the synchronous emergence of both the sexes (male and female adult moths) in all the three stem borer species observed. Baskaran et al. (2017) reported the appearance of first Yellow stem borer moth in light trap during the first week of August $\left(31^{\text {st }} \mathrm{SMW}\right)$ which favours the present result. In the entire cropping season, the moth populations of Yellow stem borer reached its peak during the last week of December $\left(52^{\text {nd }} \mathrm{SMW}\right)$ with males (13.38 no./week), females (30.88 no./week). The moth population of Pink stem borer reached its peak during the last week of December (52nd SMW) with males (36.86 no./week), females (31.86 no./week). The populations of Dark headed borer reached its peak during December (51st SMW) with trap catches of males ( 0.29 no./week) and females (1.71 no./week) during Kharif and Rabi (Fig. 1; Fig. 5). However, during Kharif2018, the population of Yellow stem borer reached its peak during second week of October, $41^{\text {st }}$ SMW and the population of PSB during fourth week of October, $43^{\text {rd }}$ SMW. The present results are in accordance with the previous report that, the infestation of $S$. incertulas was found during August to September and December to January at Thirupathisaram, Kanyakumari, Tamil Nadu (Justin and Preetha, 2013).

\section{Influence of weather parameters}

The average temperature $(30.82,28.71$ and 8.75$)$, relative humidity $(53.93,60.00$ and 71.93$)$, wind velocity $(15.91,6.40$ and 


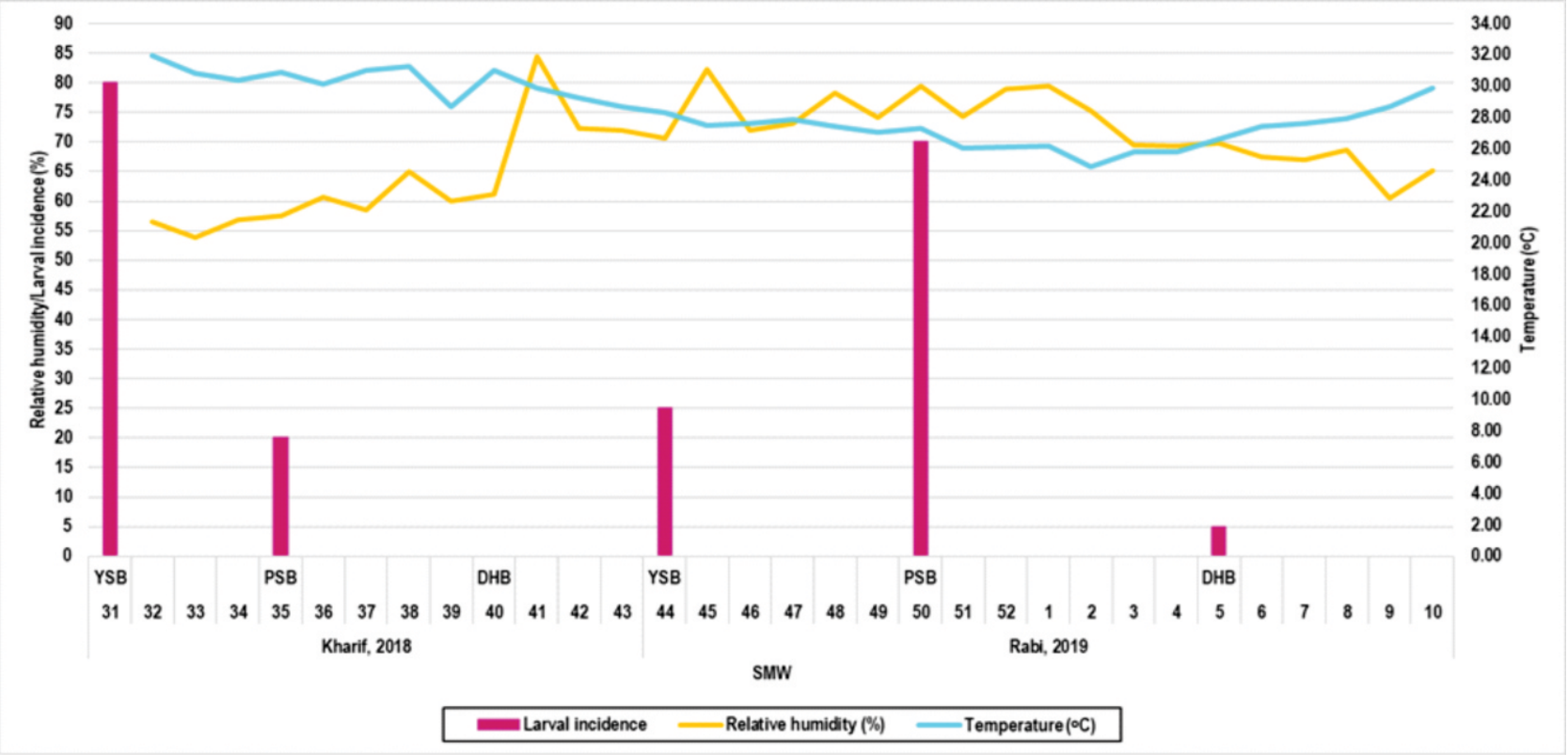

Fig. 1: Weather parameters temperature $\left({ }^{\circ} \mathrm{C}\right)$ and relative humidity $(\%)$ observed during study.

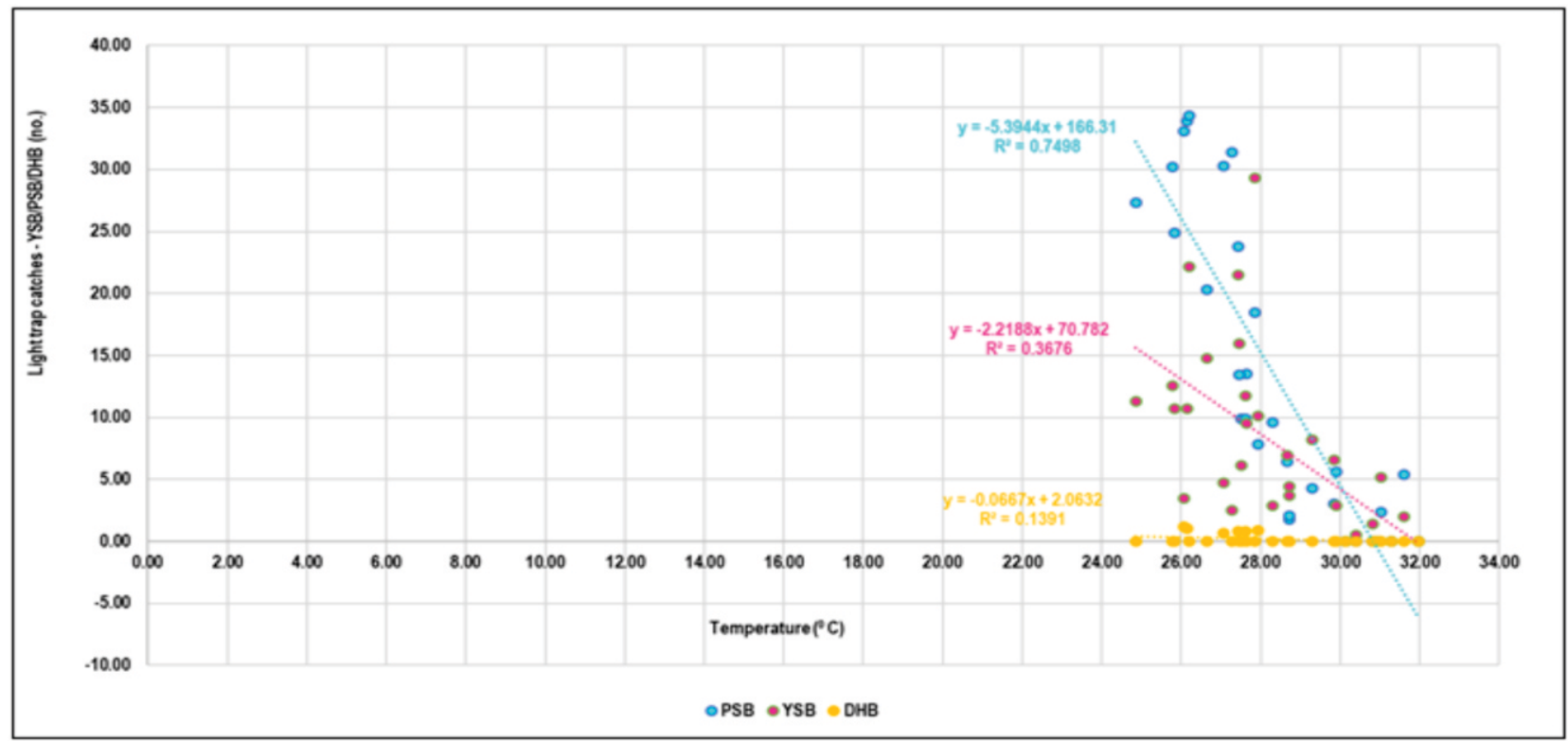

Fig. 2: Effect of temperature on the distribution of Yellow stem borer, Pink stem borer and Dark headed borer in rice ecosystem (Kharif2018 and Rabi 2019 ).

$3.03)$, sunshine hours $(2.60,6,59$ and 3.83$)$, and rainfall $(0.00$, 0.23 and 0.00 ) observed during $32^{\text {nd }}, 38^{\text {th }}$ and $42^{\text {nd }}$ SMW favoured the incidence of adult population of YSB, PSB and DHB respectively (Fig. 1 and 5). Whereas, the weather parameters such as temperature (26.19 and 26.14), relative humidity (79.50 and 78.86), wind velocity (3.73 and 5.09) and sunshine hours (5.03 and 4.59) in these ranges observed during $52^{\text {nd }}$ and $51^{\text {st }}$ SMW respectively, favored the population of Yellow stem borer, Pink stem borer and Dark headed borer to reach their peak.
The results revealed that the occurrence of Pink stem borer required comparatively lower temperature, higher relative humidity, lower wind velocity, higher sunshine hours and higher rainfall than YSB during Kharif and Rabi season. Akhter et al. (2015) reported that, Pink stem borer required comparatively lower temperature for emergence than Yellow stem borer, i.e., Pink stem borer was trapped below $32^{\circ} \mathrm{C}$ and had strong relationship with temperature. Also, maximum moth catch of PSB was observed at $58-60 \%$ relative humidity, which is in line with the 
Table 1: Influence of weather parameters on the light trap catches of rice stem borer species (Kharif, 2018 and Rabi, 2019)

\begin{tabular}{|c|c|c|}
\hline Weather parameters & Stem borer species & Correlation co-efficient \\
\hline Maximum temperature $\left({ }^{\circ} \mathrm{C}\right)$ & $\begin{array}{l}\text { YSB (M) } \\
\text { YSB (F) } \\
\text { PSB (M) } \\
\text { PSB (F) } \\
\text { DHB (M) } \\
\text { DHB (F) }\end{array}$ & $\begin{array}{l}-0.515^{*} \\
-0.581^{*} \\
-0.801^{*} \\
-0.821^{*} \\
-0.352^{*} \\
-0.387^{*}\end{array}$ \\
\hline Minimum temperature $\left({ }^{\circ} \mathrm{C}\right)$ & $\begin{array}{l}\text { YSB (M) } \\
\text { YSB (F) } \\
\text { PSB (M) } \\
\text { PSB (F) } \\
\text { DHB (M) } \\
\text { DHB (F) }\end{array}$ & $\begin{array}{l}-0.207 \\
-0.679^{*} \\
-0.725^{*} \\
-0.830^{*} \\
-0.243 \\
-0.276\end{array}$ \\
\hline Relative humidity (\%) & $\begin{array}{l}\text { YSB (M) } \\
\text { YSB (F) } \\
\text { PSB (M) } \\
\text { PSB (F) } \\
\text { DHB (M) } \\
\text { DHB (F) }\end{array}$ & $\begin{array}{l}0.452^{*} \\
0.471^{*} \\
0.988^{*} \\
0.955^{*} \\
0.234^{*} \\
0.322^{*}\end{array}$ \\
\hline Wind velocity $\left(\mathrm{km} \mathrm{hr}^{-1}\right)$ & $\begin{array}{l}\text { YSB (M) } \\
\text { YSB (F) } \\
\text { PSB (M) } \\
\text { PSB (F) } \\
\text { DHB (M) } \\
\text { DHB (F) }\end{array}$ & $\begin{array}{l}-0.398^{*} \\
-0.407^{*} \\
-0.521^{*} \\
-0.553^{*} \\
-0.200 \\
-0.188\end{array}$ \\
\hline Sunshine ( $h$ per day) & $\begin{array}{l}\text { YSB (M) } \\
\text { YSB (F) } \\
\text { PSB (M) } \\
\text { PSB (F) } \\
\text { DHB (M) } \\
\text { DHB (F) }\end{array}$ & $\begin{array}{l}-0.106 \\
0.070 \\
0.140 \\
0.208 \\
0.163 \\
0.011\end{array}$ \\
\hline Rainfall (mm) & $\begin{array}{l}\text { YSB (M) } \\
\text { YSB (F) } \\
\text { PSB (M) } \\
\text { PSB (F) } \\
\text { DHB (M) } \\
\text { DHB (F) }\end{array}$ & $\begin{array}{l}-0.391^{*} \\
-0.027 \\
-0.224 \\
-0.263 \\
-0.189 \\
-0.187\end{array}$ \\
\hline
\end{tabular}

M - Male, F- Female, *Significant at $p=0.05$

present findings. Maximum PSB adults were trapped, when the maximum temperature (29.7 and 36.4$)$, minimum temperature (16.4 and 19.4) and relative humidity $(67.0$ and $47.5 \%)$ were observed in these ranges during the year 2013-14 and 2014-15 respectively (Deole, 2016).

It was clearly evident from the results, that the light trap catches of YSB male $\left(r=-0.515^{*}\right)$, YSB female $\left(r=-0.581^{*}\right)$, PSB female $(r=$ $\left.-0.263^{*}\right)$, PSB male $\left(r=-0.224^{*}\right)$, DHB male $\left(r=-0.352^{*}\right)$, and DHB female $\left(r=-0.387^{\star}\right)$ showed a significant negative correlation with the maximum temperature (Table 1). The moth population also showed a significant negative correlation with the minimum temperature, YSB female $\left(r=-0.679^{*}\right)$, PSB female $\left(r=-0.821^{*}\right)$, PSB male $\left(r=-0.189^{*}\right)$. Relative humidity played a significant positive role on YSB male $\left(r=0.988^{*}\right)$, YSB female $\left(r=0.471^{*}\right)$, PSB male $\left(r=0.988^{*}\right)$, PSB female $\left(r=0.955^{*}\right)$, DHB male $\left(r=0.234^{*}\right)$ and DHB female $\left(r=0.322^{*}\right)$ population in the light trap catches. YSB male $\left(r=-0.398^{*}\right)$, YSB female $\left(r=-0.407^{*}\right)$, PSB male $\left(r=-0.521^{*}\right)$ and PSB female $\left(r=-0.553^{*}\right)$ showed a significant negative correlation with wind velocity. The sunshine hours was positively correlated with the moth population and did not have any significant effect on the occurrence of stem borers. The Rainfall had a negative correlation with the moth population, YSB male $\left(r=-0.391^{*}\right)$, YSB female $(r=-0.027)$, PSB male $(r=-$ $0.244)$, PSB female ( $r=-0.263)$,DHB male $(r=-0.189)$ and DHB female $(r=-0.187)$ with a significant effect on YSB population (Table 1). Thus, the moth catch showed a significant negative correlation with the maximum and minimum temperature, rainfall and wind velocity, which indicated a decline in the population of stem borer species with increase in those abiotic factors. Whereas, relative humidity and sunshine hours had positive correlation with the moth catch of stem borer species. The population of stem borer species were found to increase as relative humidity and sunshine hours increased. Kakde and Patel (2014), documented that, the YSB population was positively correlated with relative humidity. Hugar et al. (2009) reported a significant positive correlation between YSB and sunshine hours and negative correlation with maximum temperature, which agrees 


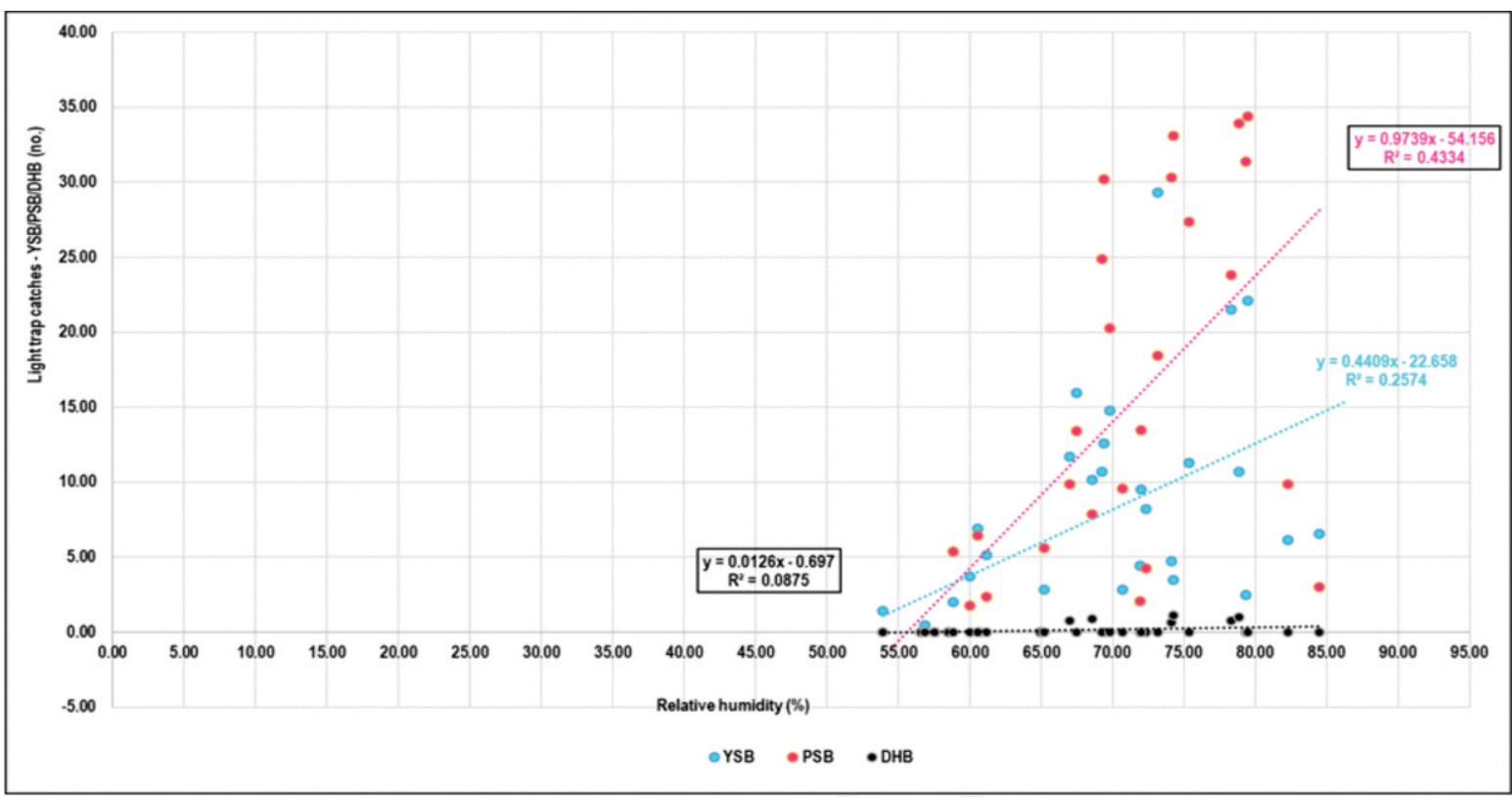

Fig. 3: Effect of relative humidity on the distribution of Yellow stem borer, Pink stem borer and Dark headed borer in rice ecosystem (Kharif 2018 and Rabi 2019 ).

with the present findings. Relative humidity was positively correlated with the trap catches by providing conducive environment for the emergence of adults of stem borer species, while rainfall was negatively correlated (Baskaran et al., 2017). Singh and Kular, (2015) reported the negative effect of maximum and minimum temperature and postivie effect of relative humidity on the population build up of PSB.
Thus the results on correlation between abiotic factors and stem borer species distribution based on light trap catches indicated that the seasonal distribution of stem borer species in rice ecosystem was significantly influenced by temperature, relative humidity and wind velocity. The linear regression equations indicated that in every one unit increase in temperature, $0.37 \%, 0.75 \%$ and $0.14 \%$ decrease in the

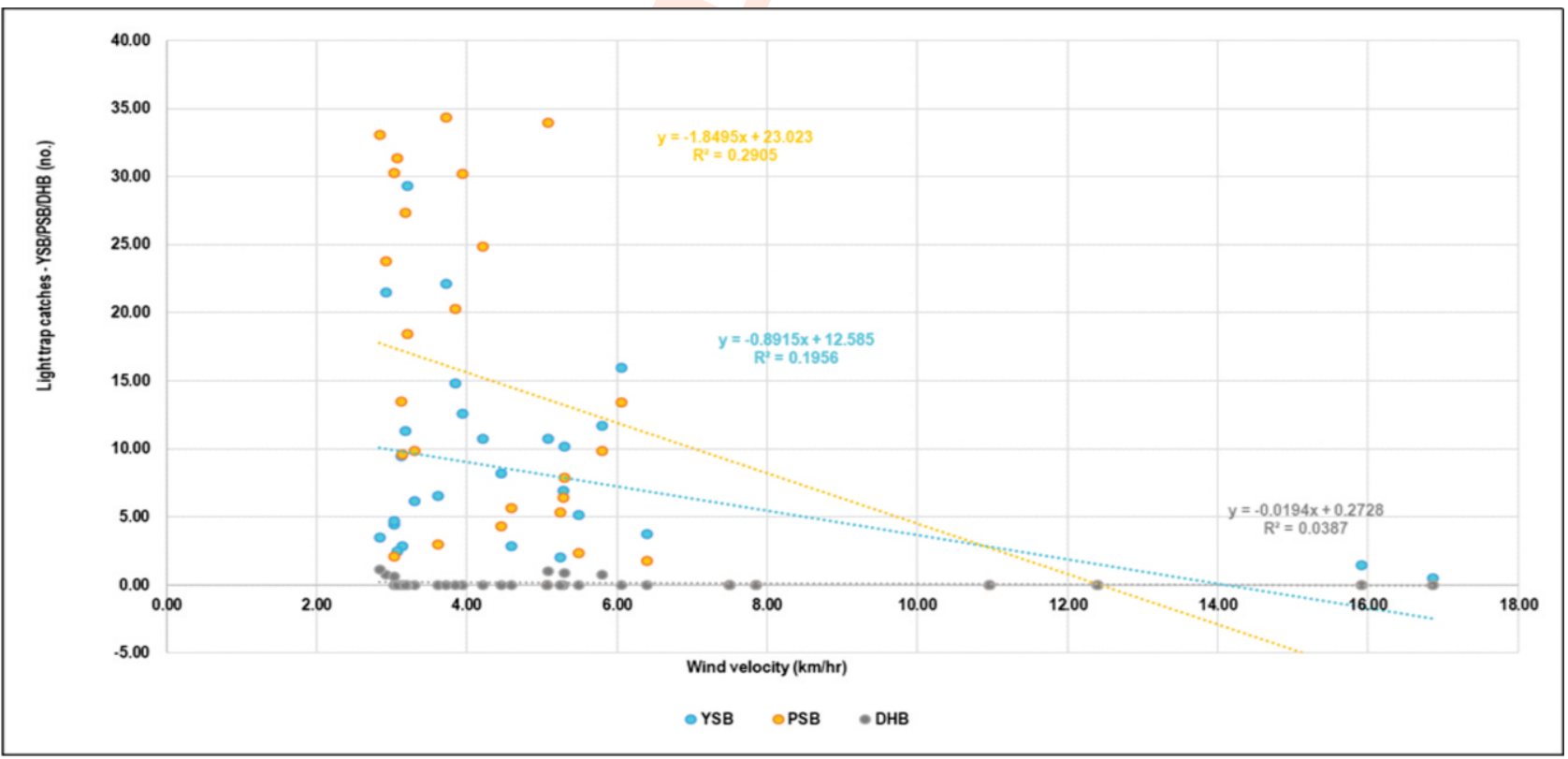

Fig. 4: Effect of wind velocity on the distribution of YSB, PSB and DHB in rice ecosystem (Kharif, 2018 and Rabi, 2019). 
Table 2: Relative abundance of stem borer species in rice

\begin{tabular}{|c|c|c|c|c|c|c|}
\hline \multicolumn{7}{|c|}{ Relative abundance $(\%)^{*}$} \\
\hline \multirow[t]{2}{*}{ Season } & \multicolumn{2}{|l|}{ Light trap catches } & & \multicolumn{3}{|c|}{ (Dead heart/ white ear) Larval incidence } \\
\hline & Yellow stem borer & Pink stem borer & Dark headed borer & Yellow stem borer & Pink stem borer & Dark headed borer \\
\hline Kharif, 2018 & 80.61 & 19.39 & 0.00 & 80.00 & 20.00 & 0.00 \\
\hline Rabi, 2019 & 21.92 & 72.60 & 5.48 & 19.12 & 75.00 & 5.88 \\
\hline
\end{tabular}

*Mean of weakly observations

occurrence of YSB, PSB and DHB populations was found, in the rice ecosystem (Fig. 2). However, every one unit increase in relative humidity, there would be $0.26 \%, 0.43 \%$ and 0.09 \%increase in the incidence of YSB, PSB and DHB adult population respectively (Fig. 3). Similarly, each unit increase in wind velocity had $0.19,0.29$ and $0.04 \%$ effect in decreasing the populations of YSB, PSB and DHB respectively (Fig. 4). Adiroubane and Raja, (2010) reported that for every one unit increase in morning relative humidity, evening relative humidity, wind velocity, sunshine hours and dewfall, there would be 0.09 , $0.08,0.34,0.09,0.12$ and $0.40 \%$ increase of stem borer damage, respectively.

The relative abundance of stem borer species based on light trap catches showed the occurrence of YSB (80.61\%), PSB (19.39\%) and DHB (0.0\%) during Kharif, 2018 and in Rabi 2019, witnessed PSB (72.60\%), YSB (21.92\%) and DHB (5.48\%) (Table 2). Thus it clearly indicated the dominance of YSB during Kharif, 2018 and PSB during Rabi, 2019, which coincided with the maximum larval incidence of YSB $(80.00 \%)$ during Kharif and PSB (75.00\%)during Rabi (Fig. 1). This was in agreement with the findings that, $S$. inferens started egg laying in the field during $45^{\text {th }}$
SMW to $48^{\text {th }}$ SMW (first to last week of November) (Sharma et al., 2017). Baskaran et al. (2017) reported a reduction in the damage and trap collection of YSB, beyond $43^{\text {rd }}$ SMW (Kharif), which coincides with the dominant occurrence of PSB during Rabi than the population of YSB in the present study. However, Gagan et al. (2009) reported the predominant occurrence of YSB throughout the season, while PSB was dominant towards the maturity of crop.

The present findings are further supported by the report that YSB was the most predominant species in both $\operatorname{Kar}(60.00 \%)$ and Pishanam (48.83\%) season. PSB was found to be the second most dominating species in $\operatorname{Kar}(35.21 \%)$ and was as abundant as YSB in Pishanam (48.43\%). DHB was found to have least occurrence in both the seasons (4.29-7.18\%) (Ragini et al. 2000). The relative abundance of stem borer species and their natural enemies revealed that, YSB was dominant followed by DHB, PSB, white stem borer and striped stem borer (SSB) (Rahaman et al., 2014). Akhter et al. (2015) reported that, YSB and WSB were dominant from mid- March to May and from August to midOctober, while PSB was dominant from September to first week of April which is in line with the present findings of PSB in Rabi.

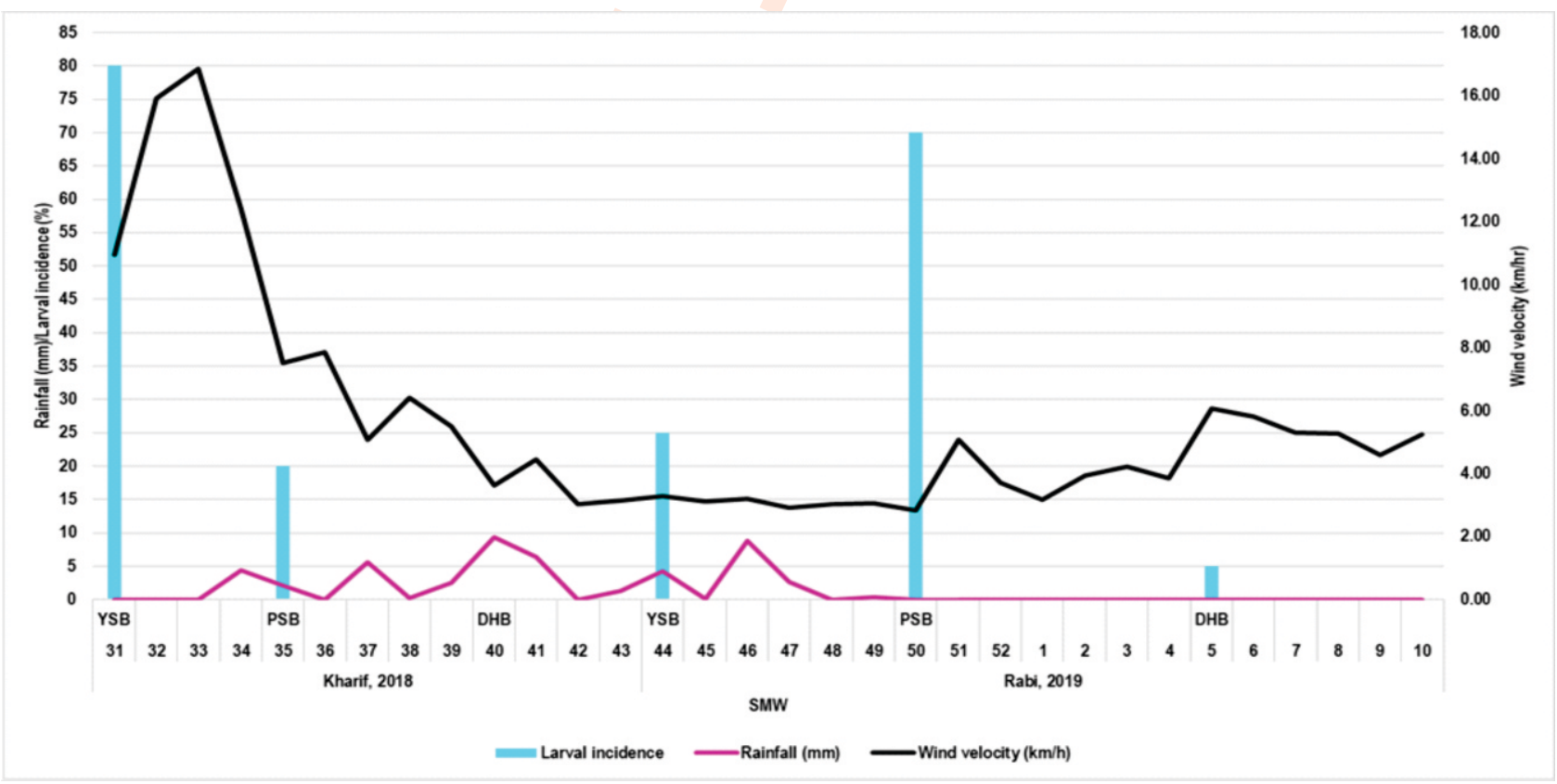

Fig. 5: Weather parameters rainfall $(\mathrm{mm})$ and wind velocity $\left(\mathrm{km} \mathrm{hr}^{-1}\right)$ observed during Kharifand Rabi. 
The reduction in temperature and increase in relative humidity during Rabi, 2019 to Kharif, 2018 favoured the dominant occurrence of PSB than the YSB and DHB species during Rabi (Fig. 2 and 3). The data subjected to regression analysis confirmed the increased effect of temperature $\left(R^{2}=0.75 \%\right)$, relative humidity $\left(R^{2}=0.43 \%\right)$ and wind velocity $\left(R^{2}=0.29 \%\right)$ on the population of PSB than YSB in rice ecosystem during Kharif and Rabi. Temperature ( 25 to $27^{\circ} \mathrm{C}$ ), relative humidity ( $69-80 \%$ ) and wind velocity $\left(3-4 \mathrm{~km} \mathrm{hr}^{-1}\right)$ increased the fitness of PSB than YSB and DHB species in rice ecosystem (Fig. 2, 3, 4). These factors favoured the dominant occurrence of PSB during Rabi, 2019 than YSB and DHB species.

Considering rice stem borer, YSB, PSB, DHB, SSB and WSB have been reported to occur in South - East Asia (Rahaman et al., 2014). Among these, YSB is the widely distributed and predominantly occurring species than other stem borer species in rice ecosystem. YSB was more abundant $(63.9 \%)$ than PSB (22.8\%) and DHB (13.3\%) in seven agro climatic regions of Tamil Nadu (Ragini et al. 2000). It is the fluctuations in the weather parameters, as climate change in the long run influenced the incidence and relative abundance of PSB species in the rice ecosystem.

Jiang et al. (2005) reported that increase in each unit of white ear damage has a greater impact on rice yield. Globally, 50 $\%$ of the insecticides are used to manage the pest menace in rice crop (Huesing and English, 2004). Many conventional insecticides though have been evaluated against rice stem borer, yet they have failed to provide the adequate control. It is due to variation in the distribution and relative abundance of stem borer species, which was strongly influenced by the fluctuations in abiotic factors. Pesticides which were effective in managing a stem borer species showed reduced effect in managing other stem borer species population. It can be well supported by the findings of Visagie (2016) that among 14 insecticides evaluated for controlling three stem borer species in maize, two insecticides, chlorantraniliprole and chlorfenapyr were less effective in controlling $B$. fusca, and were effective in controlling $C$. partellus and Sesamia calamistis Hampson.

Hence, before developing the management tactics for stem borer in rice ecosystem based on visual symptoms, the seasonal abundance of stem borer species has to be ascertained through light trap catches and larval incidence for the development of species specific control strategy. Also, weather based forecasting models on the occurrence and relative abundance of stem borer species in rice ecosystem can be developed for an effective management of rice stem borer, thereby increasing the production and food security.

\section{Add-on Information}

Authors' contribution: T. Sharmitha: Carried out research and drafted manuscript ; C. Gailce Leo Justin: Major advisor and contributor in conceiving the research problem, implementing and compilation of data; S. Sheeba Joyce Roseleen: Minor advisor, Co-contributor in interpretation of results.
Research content: The research content is original and has not been published elsewhere.

\section{Ethical approval: NotApplicable}

Conflict of interest: The authors declare that there is no conflict of interest.

\section{Data from other sources: NotApplicable}

Consent to publish: All authors agree to publish the paper in Journal of Environmental Biology.

\section{References}

Adiroubane, D., and K. Raja: Influence of weather parameters on the occurrence of rice yellow stem borer, Scirpophaga incertulas (Walker). J. Rice Res., 3, 5-9 (2010).

Akhter, M., S. Zia, Z. Haider, and A. Makhdoom: Associating light trap catches of some major rice insect pests with prevailing environmental factors. Pakistan J. Agrl. Sci., 52, 716-722 (2015).

Baskaran, R.K. Murali, K.C. Sharma and J. Kumar: Seasonal and relative abundance of stem-borer and leaf-folder in wet land rice eco-system. J. Entomol. Zool. Stud.,5, 879-884 (2017).

Bhatt, N., S. Joshi and S.N. Tiwari: Pests of rice. In: Pests and Their Management (Ed:Omkar). Springer Nature, Singapore Pte Ltd., pp. 9-50 (2018)

Dhaliwal, G.S., V. Jindal and A.K. Dhawan: Insect pest problems and crop losses: changing trends. Indian J. Ecol.,37,1-7 (2010).

Dhivahar, P. and N. Dhandapani: Bioefficacy of the new molecule, Thiacloprid (Calypso 240 SC) against rice yellow stem borer, Scirpophaga incertulas (Walker). Indian J. Plant Prot.,31,144-145 (2003).

Fukagawa, N. K. and L.H. Ziska. Rice: Importance for global nutrition. J. Nutri. Sci. Vitaminol., 65, S2-S3 (2019).

Gagan, J., R. Lakhi and S. Ram: Population dynamics of paddy stem borers in relation to biotic and abiotic factors. Ann. Biol., 25, 47-51 (2009).

Gupta, S.P., R.A. Singh and A.K. Singh: Field efficacy of granular insecticides and single compound sprays against pests in rice. Indian J. Entomol., 68, 150-151 (2006).

Hattori, I.: Stem borer of gramineous crops in South-East Asia. In: Proceedings of a Symposium on Rice Insects. Tropical Agricultural Research Centre, Tokyo, Japan, pp.143-153 (1971).

Huesing, J. and L. English: The impact of Bt crops on the developing world. J. Agr.Bio. Manage. Econ.,7,84-95 (2004).

Hugar, S.V., M.I. Naik and M Manjunatha: Comparative biology of yellow stem borer, Scirpophaga incertulas Walker in aerobic and transplanted rice. Mysore J. Agrl. Sci.,43,439-443 (2009).

Jiang, Y., H. Duan, J. Li, L. Yuan, Z. Wang, C. Gong, and Q. Pei: Current situation and control counter measures of eventful rice diseases and pests in Shanghai suburbs. Shg. Nongye Xuebao, 21, 78-81 (2005).

Justin, C.G.L. and G. Preetha: Seasonal incidence of rice yellow stem borer, Scirpophaga incertulas (Walker) in Tamil Nadu. Indian J. Entomol., 75, 109-112 (2013).

Kakde, A.M. and K.G. Patel: Seasonal Incidence of rice yellow stem borer (Scirpophaga incertulas W/k.) in relation to conventional and sri methods of planting and its correlation with weather parameters. J. Agric. Vet. Sci.,7,05-10 (2014).

Khan, Z. R., J. A. Litsinger, A. T. Barrion, F. F. D. Villanueva, N. J. 
Fernandez and L. D. Taylo: World bibliography of rice stem borers: 1794-1990. International Rice Research Institute, Phillipines (1991).

Kumar, S.D.: Rice Production in India: Analysis of Trend, Constraints and Technologies. In: Climate Change and Future Rice Production in India. India Stud. Bus. Econ. Springer, Singapore (2019).

Mathur, K.C., P.R. Reddy, S. Rajamani and B.T. Moorthy: Integrated pest management in rice to improve productivity and sustainability. Oryza,36,195-207 (1999).

Mwalusepo, S., H.E. Tonnang, E.S. Massawe, G.O. Okuku, N. Khadioli, T. Johansson and L.B.P. Ru: Predicting the impact of temperature change on the future distribution of maize stem borers and their natural enemies along East African mountain gradients using phenology models. PIOS ONE, 10, $01-23$ (2015).

Pasalu, I. C. and G. Katti: Advances in ecofriendly approaches in rice IPM. J. Rice Res. 1, 83-90 (2006).

Preetha, G.: Screening of rice cultures/germplasm for resistance to stem borer." J. Entomol. Zool. Stud.,5, 2007-2010 (2017).
Ragini, J. C., D. Thangaraju and P.M.M. David: Stem borer species composition in Tamil Nadu, India. Int. Rice Res. Notes, 25, $01-15$ (2000).

Rahaman, M.M., K.S. Islam, M. Jahan and M.A.A. Mamun: Relative abundance of stem borer species and natural enemies in rice ecosystem at Madhupur, Tangail, Bangladesh. J. Bangladesh Agric. Univ., 12, 267 - 272 (2014).

Sampath, K.M., S. Chitra, M. Mohan, Padmavathi, K. Subaharan and G. Katti: Emergence pattern reproductive biology and courtship behaviour of rice pink stem borer, Sesamia inferens (Walker) (Noctuidae; Lepidoptera). Agrotechnol., 2, 60 (2014).

Sharma, H., M.S. Jaglan and S.S. Yadav: Biology of pink stem borer Sesamia inferens (Walker) on maize, Zea mays. J. Appl. Nat. Sci., 9, 1994-2003 (2017)

Singh, B. and J.S. Kular: Influence of abiotic factors on population dynamics of pink stem borer Sesamia inferens Walker in ricewheat cropping system of India. J. Wheat Res., 7, 23-28 (2015). 